\title{
REGULATORY ENVIRONMENTS AND THE LOCATION DECISION: EVIDENCE FROM THE FIRST FOREIGN MARKET ENTRIES OF NEW TECHNOLOGY-BASED FIRMS
}

\author{
Regis Coeurderoy ${ }^{1}$ \\ Gordon Murray ${ }^{2}$
}

University of Exeter

Discussion Papers in Management

Paper number 06/04

ISSN 1472-2939

(Running title: Regulatory Environments and Internationalization)

The authors gratefully acknowledge the financial support of The Anglo-German Foundation for the Study of Industrial Society in helping fund this on-going research program

\footnotetext{
${ }^{1}$ CRECIS,Louvain School of Management, Universite Catholique de Louvain, Place des Doyens, 1, B-1348 Louvain-La-Neuve, Belgium. Tel 3210473384 Fax 3210473484 coeurderoy@poge.ucl.ac.be

${ }^{2}$ Correspondence address: School of Business and Economics, University of Exeter, Streatham Court, Rennes Drive, Exeter EX4 4PU, United Kingdom Tel: +44 (0) 1392 264501, Fax: +44 (0) 1392 263242, Email: gmurray@exeter.ac.uk
} 


\title{
Regulatory environments and the location decision: Evidence from the first foreign market entries of new technology-based firms
}

\begin{abstract}
New technology based firms (NTBFs) embarking on a strategy of rapid internationalization choose foreign market entries which minimizes transaction costs and the related risks of failure. Means to reduce the young firms' vulnerability to the appropriation of intellectual capital are particularly important influences on early foreign market choices. We explore specifically the effect of national 'regulatory environments' on the decision to internationalize and on the location choices made by British and German NTBFs. We provide evidence that entrepreneurial young firms choose to enter country markets offering better regulatory protection for their intellectual property. This decision is moderated by a home regulatory regime bias. In contrast, we observe that the foreign regulatory regime much less affects the speed of internationalization which is more influenced by industry and firm characteristics.
\end{abstract}

Key Words:

New technology-based firms; internationalization; intellectual property rights; regulatory environment 


\section{INTRODUCTION}

The international activities of new technology-based firms (NTBFs) have become of increasing importance to academic researchers (McDougall, Shane \& Oviatt, 1994; McDougall \& Oviatt, 2000; Zahra, Ireland \& Hitt, 2000; Autio, 2005; Zahra, 2005). For those firms internationalizing rapidly in their early years, strategic issues regarding internationalization choices have to be addressed quickly (Madsen \& Servais, 1997; Oviatt \& McDougall, 1995; Zahra and George, 2002). One of Oviatt and McDougall’s (1994) key insights was that, in their rapid development, these nascent firms do not follow a sequential and incremental learning process described by the internationalisation stage theory (Johanson and Vahlne, 1977 and 1990). INVs do not wait for the accumulated ownership of resources. They internationalise despite having limited market knowledge and negligible advantages of size. Accordingly, the act of internationalization while a potentially valuable economic opportunity also may significantly increase the vulnerability of the young firm when competing in new foreign markets. For that reason, the first strategic question the internationalizing NTBF must address is the selection and priority of foreign markets in the light of the risks to the firm that this decision will incur.

Based upon recent theoretical advances in the institutional analysis of countries and their influence on business transactions (La Porta et al., 1999; Henisz, 2000; World bank, 2006) including intellectual capital valuation in property rights (Ginarte and Park, 1997; Oxley, 1999; Ostergard, 2000), we thus explore how regulatory differences across countries impact on the location choices of rapidly internationalization NTBFs. Specifically, we look at the influence of country-specific legal domains on: i) the decision to internationalise; ii) the ordered choice of foreign markets entered; and iii) the speed at which successive foreign markets are entered. We argue that, the resource and experience constraints on young firms limit their strategic choices. They will enter later regulatory environments where there is a 
danger of incurring large and/or uncertain transaction costs. In the choice of countries entered a bias to replicating the domestic environment of the NTBF is also observed. By their actions, management seeks to reduce the associated transaction and time costs of internationalization (Anderson \& Gatignon, 1986) and thus manage the threats to their firm, particularly from expropriation or imitability of its core intellectual property (IP) assets (Teece, 2000).

In focusing on the initial decisions to internationalize undertaken by a cohort of high-tech young firms in Germany and the United Kingdom, with information on the timing and order of markets entered, we have the opportunity to explore the influence of the environment dynamically. In so doing, we help address Zahra's (2005) concern that aspects of economic geography have been overlooked in internationalization theory, as well as answering in part Zahra's further question as to what happens to INVs once they go abroad. While German and UK firms are both established European economies, they continue to operate under markedly different national regulatory frameworks (La Porta et al., 1998 and 1999; World Bank, 2006) $)^{1}$. They also demonstrate clearly divergent behavior over time in the internationalization actions of their NTBFs (Bürgel et al, 2004). Having a cross country sample thus provides the opportunity to develop a comparative approach on the impact of regulatory hazards ${ }^{2}$ on the internationalization dynamics of start-ups through their selection of locations.

The first part of this paper summarizes the relevant theoretical literature. A set of grounded research hypotheses is then formulated. The research methodology is discussed in section two. In the third section, the empirical model and results are presented prior to a discussion of the implications of our findings. The paper concludes with an overview and notes some limitations of the study.

\footnotetext{
${ }^{1}$ As an example, in the most recent "Ease of doing business" ranking made by the World Bank (2006), the United Kingdom was ranked $6^{\text {th }}$ and Germany $21^{\text {st }}$ in the world; $4^{\text {th }}$ and $15^{\text {th }}$ respectively for OECD countries only.
} 


\title{
Regulatory environments and the location decision: Evidence
}

from the early foreign market entries of new technology-based

firms

\author{
REGIS COEURDEROY \\ Corresponding author \\ CRECIS, Louvain School of Managmeent \\ Universite Catholique de Louvain \\ Place des Doyens, 1 \\ B-1348 Louvain-La-Neuve, Belgium \\ Tel 3210473384 \\ Fax $\quad 3210473484$ \\ coeurderoy@poge.ucl.ac.be
}

\section{GORDON MURRAY}

\author{
School of Business and Economics \\ University of Exeter \\ Streatham Court, Rennes Drive \\ Exeter EX4 4PU, England \\ Tel $\quad 44(0) 1392264501$ \\ Fax $\quad 44(0) 1392264425$ \\ gmurray@exeter.ac.uk
}

(Running title: Regulatory Environments and Internationalization)

The authors gratefully acknowledge the financial support of The Anglo-German Foundation for the Study of Industrial Society in helping fund this on-going research program 


\section{EARLY INTERNATIONALIZATION: EXTANT THEORY AND HYPOTHESES DEVELOPMENT}

A number of authors have argued that early internationalization of start-ups has challenged traditional theories of internationalization (McDougall et al., 1994; Oviatt and McDougall, 1994; Zahra and George, 2002; Zahra, 2005; Dimitratos and Jones, 2005). Recent research articles on international entrepreneurship deal with economic performance (Zahra et al. 2000), growth and / or survival (Autio et al., 2000; Lu and Beamish, 2006; Sapienza et al., 2006) and strategic intent (Preece et al., 1998; De Clercq and al., 2005). The very first strategic decision of internationalizing start-ups, i.e. the process of market selection (Mascarenhas, 1997), however, remains largely unexplored, as well as related questions on the speed of entry (Oviatt and McDougall, 2005). Such omissions are surprising given the importance of these decisions on subsequent firm success or failure. A better understanding of the location choices, including the importance of the protection of intellectual capital, helps enrich the debate about new models of internationalization for NTBFs.

\section{Early internationalization risks for NTBFs}

There are a range of competing arguments explaining why NTBFs seek to internationalize so quickly. It has been suggested that this phenomenon may be a result of insufficient, aggregate home demand for highly specialized, i.e. 'niche’ products and services (Madsen and Servais, 1997); or conversely that overseas sales are the individual firm's response to excessive domestic competition (Shrader, 2001). These arguments are essentially a description of defensive actions by firms 'pushed out' or beyond home markets. A more proactive interpretation is that internationalization provides additional sales opportunities for a product or service enjoying a competitive advantage beyond domestic borders (Sapienza et al,

\footnotetext{
${ }^{2}$ We use the term 'hazard' to describe a set of diverse uncertainties emanating from the international business environments in which the firm trades that threaten or erode the economic rents of the firm (Henisz, 2000).
} 
2006). Yet, regardless of the strategic logic of internationalization, NTBFs have to accept the imminent prospect of additional technology transfer risks when entering into foreign countries.

The impact of host country features on the costs of international technology transfers has been studied in a long tradition in international business research (Buckley, 2004) and has enabled the specific features of international transactions to be identified and modeled. Host countries specificities represent a large part of the "liability of foreignness" (Zaheer, 1995) that new ventures experience at the beginning of the internationalization process. Equibus paribus, every company will incur additional transaction costs when setting up international operations. For example, on entering a new country market, the as yet inexperienced firm will likely discover that it is difficult: i) to find good and reliable local sales agents - an increase in search costs; ii) to negotiate favorable contractual arrangements - an increase in ex ante negotiation cost; or iii) to monitor effectively the concluded deal - an increase in ex post compliance and enforcement costs (Teece, 1986).

These problems are exacerbated in the specific case of NTBFs The transfer of novel technologies raises potential problems of appropriation (Autio, Sapienza and Almeida, 2000; Zahra et al., 2000). The complexity and intangibility of the technological component of the product or service by its very ambiguity exacerbates the contractual hazard for NTBFs (Knight and Cavusgil, 2004). Because these hazards are specific to the imitability of the technology being transferred, the young firm has little choice other than to accept, and attempt to mitigate, the increase risks of international trading. Consequently, the young firm's flexibility is reduced to determining the level of additional costs that it can reasonably bear given expected revenues. The default for established firms is to treat transaction costs as part of a set of computed debits and credits for established firms (Buckley and Casson, 1976). A firm may be prepared to accept higher transaction costs in a new country if greater profits can 
be secured. This approach views transaction costs as one of a set of contingent costs to be accommodated in the overall decision to internationalize. We suggest that this interpretation under-estimates the potential impact of transaction costs on young firms. The main problem is not that the firm's total costs are increased but, rather, that the possibility of firm failure is made materially higher by the circumstances that generate these new costs (Hennart, 1986). It is not just specific market risks that have increased in the new environment but also the number of potential environmental hazards now facing the young (and vulnerable) firm. Given that a majority of new firms will die within three years of formation (Cressy, 2006), the computation of transactions costs is not merely the determination of net incremental benefit. The chances of a young firm recovering from a major strategic error incurring significant unplanned costs is remote (Thornhill and Amit, 2003). Misjudgments are likely to result in death not sunk costs (Sapienza et al., 2006).

\section{Country regulations and location choices by NTBFs}

Accordingly, the success or the failure of the fledgling enterprise on entering a new foreign market will be linked with the additional level of threat to its proprietary intellectual assets. The inability to define 'complete' contracts, and importantly for NTBFs the lack of resources to defend their legal rights, is likely to encourage opportunistic behavior by local players having better knowledge of domestic regulatory frameworks and business mores. These potential threats include the "hold-up" of specific assets (Williamson, 1991; Anderson and Gatignon, 1986; Oxley, 1997); appropriation or technological leakage (Davidson, 1980; Oxley, 1999); and 'free riding' on brand name and reputation (Anderson and Coughlan, 1987; Delios and Beamish, 1999).

Firms with attractive IP assets are thus vulnerable to predation when property rights are not clearly defined (Reitzig, 2004). The ambiguity and complexity of local regulations and 
legislation are likely to generate important hazards in technological transfers. This regulatory context is defined by Davis \& North (1971: 6-7) as "the set of fundamental political, social and legal ground rules that establishes the basis for production, exchange and distribution. Rules governing elections, property rights and right of contracts are examples...” Regulation includes "he related governance measures by which societies attempt to create structure and stability for human interaction” (North, 1990) ${ }^{3}$. Regulation particularly plays a decisive and direct role on property rights (Barzel, 1989), which are critical for NTBFs developing abroad their competitive advantage embedded in the core intellectual assets of their innovation (Teece, 2000).

Authors argue that some regulatory frameworks are more protective of business transactions than others (Hennart, 1986, Williamson, 1991; La Porta et al., 1998; World Bank, 2006). Countries providing weak property rights protection and/or high levels of political uncertainty will increase the transaction costs of firms operating within their borders (Oxley, 1999). Conversely, in countries with strong and enforceable property rights within stable political regimes, firms will bear less costs of uncertainty (Williamson, 1991). La Porta et al. (1998 and 1999) argue that the protection of individuals' property rights remains greater in Common Law than in Civil Law. Therefore, for the NTBF seeking to internationalize at an acceptable level of hazards, its trust in the regulatory environment of target countries will become an important choice variable. Both the quality of foreign law enforcement (i.e. fairness, speed and cost) and the normative value system (i.e. primacy of the interests of the individual or the state) will have major cost implications for the firm faced with the threat of commercial or criminal malfeasance in foreign markets. On the basis of our argument, we

\footnotetext{
${ }^{3}$ More precisely, these authors use the expression “institutional environment”. But, as pointed out by Scott (1995), if we see the neo-institutional tradition from a wide angle, institutional environment is made of three dimensions, namely regulatory, normative and cognitive. Because our research is focused on the first statement, we prefer about the term "regulatory environment" in order to limit possible confusions with other views of institutional environment.
} 
would expect that the young, internationalizing NTBF is likely to focus on those countries exhibiting a lower level of regulatory hazards.

Hypothesis 1: $\quad$ New technology-based firms are more likely to initiate their internationalization activities by selecting target countries with lower levels of regulatory hazards.

These hazards can have both "absolute" and "relative" dimensions. A new regulatory environment generates absolute hazards when the host country fails to create stable frameworks suitable for the successful development of new business (Henisz, 2000; Shrader et al., 2000). But, in relative terms, an environment can still produce hazards for a firm if it has widely different practices from those operating in the exporting firm's domestic environment. For young and resource-constrained NTBFs, an ill-judged decision to enter a hostile and unproductive foreign market may imperil their very survival. As experiential learning tends to reinforce the blueprint of initial choices, firms are also likely to be biased by the lessons they have already learned. Since early location choices are positively influenced by the similarity of the regulatory environments between home and host countries, it can be expected that the home country will continue to represent a strong influence on the selection of foreign markets (Barkema and Vermeulen, 1997).

This determinism will be particularly observable when the start-up benefits from a wide choice of sequential target markets with regulatory environments similar or comparable to its home country. The transaction costs from regulatory hazards will remain lower in this group. By contrast, an internationalizing young firm originating from a country with a less common regulatory regime will have to face more quickly the hazards of unfamiliar regulatory environments. Accordingly, its pattern of international market entries over time is likely to be less predictable than for those firms domiciled in a more common regulatory environment. 
NTBFs will show a preference for early market entries into target countries exhibiting similar regulatory environments to their domestic markets.

Hypothesis 2a: $\quad$ NTBFs founded in the UK will prefer to enter target countries regulated by common law.

Hypothesis 2b: NTBFs founded in Germany will prefer to enter countries regulated by German civil law (but at a lower extent than UK start-ups).

\section{The role of managerial experience in early internalization choices by NTBFs}

Start-ups in their early years have little firm-level experience on which to base routines. Accordingly, the influence of the entrepreneurs and founder managers on the survival and success of young firms can be profound (Cooper, Gimeno-Gascon and Woo, 1994). NTBFs are often started by managers with international experience given the transnational character of technological innovation (Sapienza et al., 2006). It would therefore be expected that prior managerial experience will help compensate for organizational inexperience (Cooper and Dunkelberg, 1986) and will play an important part in the initial decision for the NTBF to internationalize its sales activities. However, not all experience is of equal value. We would expect professional managers who have been employed by multinational firms will have an understanding of market dynamics and industry networks as well as reputational assets of particular value to internationalizing NTBFs (McDougall et al, 1994).

Hypothesis 3a: $\quad$ New technology-based firms are more likely to internationalize where founders and senior managers have prior international experience. 

where founders and senior managers have prior international experience in multinational companies.

\section{Speed of Foreign Market Entry}

The issue of market selection and speed of entry are intrinsically related in the dynamics of internationalization by NTBFs (Arenius, 2005). Oviatt and McDougall (2005) identify four types of influence: i) the technology conditions enabling the accelerated internationalization, ii) the industry conditions motivating acceleration, iii) the entrepreneur profile, in particular in terms of experience, mediating the propensity to go abroad, and iv) the moderating forces of foreign market knowledge and network intensity. This argumentation on the dynamics of internationalization is based on an assessment of the entrepreneurial capabilities of NTBFs to identify and grasp rapidly business opportunities while managing the threats resulting from lack of experiential knowledge in foreign markets.

We employ the theoretical model of Oviatt and McDougall to explore issues relating to the speed of internationalization by NTBFs. For such firms human capital is of critical importance. The greater the international experience of the young firm's management, the more likely the firms will exploit this knowledge to enter quickly successive foreign markets. Hypothesis 4: $\quad$ New technology-based firms where founders and senior managers have prior international experience will enter foreign markets more quickly than NTBFs where founders and senior managers have no prior international experience

We would also expect that countries providing more protective business environments will require internationalizing firms to accumulate less specific local knowledge prior to entry. Such foreign markets can be entered more quickly. Accordingly, we would expect that 
countries securing business transactions and intellectual property rights will be able to attract start-ups more quickly than their peers with less protective regulatory environments.

Hypothesis 5: New technology-based firms are likely to enter more quickly target countries with lower levels of regulatory hazards.

\section{RESEARCH DESIGN AND METHODOLOGY}

\section{Longitudinal and multi-country studies}

Rialp, Rialp and Knight (2005) in reviewing a decade of academic studies of the phenomenon of early internationalizing firms place emphasis on the need for "longitudinal surveys of a large scale, representative sample of firms” (p. 163). Autio (2005) and Zahra (2005) also note the need for longitudinal studies linked to both strategy and performance outcomes of firms that are now 'middle aged'. The present paper is based on a panel survey that was first started in 1997 with the original cohort of NTBFs interviewed in both 1997 and 2002/3. Firms were on average seven and twelve years of age at the time of the two surveys. This present study's data relate to five first foreign market choices made during the respondent firms’ initial years after formation.

\section{Germany and the United Kingdom}

The selection of Germany and the UK for the research study deserves explanation. As two of Europe’s major economic powers, they are broadly comparable in socio-demographic and economic characteristics. From a regulatory perspective, however, the contemporary governance of German and UK enterprises originates from two quite different traditions, i.e. ‘German Civil Law’ and 'Common Law’, respectively. La Porta et al., (1999) demonstrate the extent to which the contemporary institutional framework of nation states can be traced back to five basic domains: namely, the English, French, German, Scandinavian and Socialist 
systems. La Porta et al. (1999) also sustain that the protection of the property rights of the individual remains greater in Common Law than in Civil Law.

A key function of the legal domain is that it may be treated as exogenous to a country's structure of corporate ownership and finance (La Porta et al, 1999: 1126). The two countries chosen allow us considerable heterogeneity from the environments, actions and choices of sampled firms (World Bank, 2006). Outside the peculiarities of the differing legal systems, these two member states of the European Union were broadly comparable in terms of the numbers and types of high-tech firms created, sector composition, and the entrepreneurial resources at the young firms’ disposal.

\section{Survey and Sample Selection}

Four criteria were used to identify the sampled firms: i) A start-up is taken to be 'a legally independent company formed within the ten years preceding the survey', i.e. in the 1987-1996 period; ii) Identification of NTBFs is initially based on sector affiliation (Storey and Tether, 1996) prior to respondent assessment. The selection of the high-technology sectors follows the definition proposed by Butchart (1987) and the OECD (1997); iii) All firms which had less than three employees were excluded from the survey. It was assumed that internationalisation is not (yet) a critical issue for the majority of these micro-firms; and iv) All firms in both manufacturing and service sectors were individually assessed to remove those firms that were not involved in research and development activities.

The final sample resulting from this process was 5,045 German firms and 3,562 UK firms. 2,000 firms were each selected from both the Germany and the UK samples. A 'stratified random sampling approach' was adopted. First, the national samples was separated into manufacturing and service categories, and further subdivided into four employee size groups 
(3-5; 6-9; 10-19; 20+) ${ }^{4}$. The pre-tested survey instrument was addressed to a named director of the company, usually the CEO or chairman. After checking the returned surveys, a 'clean' sample of 362 firms in the United Kingdom and 232 companies in Germany was achieved. The final sample of completed questionnaires met several tests of representativeness, including firm size, age and sector, despite the survey response rate being higher in the UK (24\%) than in Germany (14\%). The response rates within the strata were distributed in a similar way suggesting a low selectivity bias in the response behavior of firms in both countries.

Because several surveyed companies had not yet made any foreign sales, the sub-sample of interest was 241 (67\%) internationalizing firms in England and 134 (58\%) equivalent firms in Germany. However, for the purposes of the present study, our unit of analysis is not the firm but rather the firm's initial foreign market entries. The respondent questionnaire provided information on the first five foreign market entries for each company including the identities of the target countries and the dates of first entry. Reconfiguring the data set accordingly allowed information on 945 foreign market entries by the British companies and 451 foreign market entries by the German companies - a total of 1,396 separate entries in 71 countries. The average UK and German firms were 7.08 and 6.49 years old, respectively, at the time of the survey. Further, on realizing their first foreign entry, the UK and German NTBFs were 2.22 and 1.63 years old.

Following methodology developed in previous research (Henisz, 2000; Delios and Henisz, 2003), we take into account in our analysis those countries which are not entered by our respondent firms. From our sample we can expect a maximum of 26,625 possible entries (pairing of 375 firms for 71 countries) including 25,230 non-entries. Because of missing data, we finally obtain a sample of 18,750 observations including 1,235 realized entries.

\footnotetext{
${ }^{4}$ This size classification is popularly used for small \& medium sized enterprise information. See, for example, UK government VAT registrations.
} 


\section{Dependent Variables on Entry}

In order to study the dynamics of entry by NTBFs, we examine three distinct variables.

Foreign Entry A dummy variable indicating if firm i has entered country j (0 for "no"; 1 for “yes”). The analysis of this variable helps determine the main factors favoring international commitment.

Entry ranking Our second variable is a 'ranking' illustrating the order of selection of new country markets. It allows us to test for the importance of regulatory factors on the ordering choice. The dependent variable is assigned one of five categorical values for each respondent firm, i.e. “ 1 ” for the initial market entry up to “5” for a fifth market entry. A new foreign entry is defined as 'the first time a company generates sales from another country'. A ranking variable allows us to study the dynamics of market entries by start-ups. This is important because, as noted, in contrast to previous studies based upon more traditional patterns of industry development (Mascarenhas, 1992; Tan \& Vertinsky, 1996), the speed of internationalization of NTBFs can be very high (Oviatt and McDougall, 1995; Zahra et al., 2000; Bürgel et al., 2004). Moreover, we are interested in the cumulative number of entries classified by category of target country. As suggested by other researchers (Benito and Gripsrud, 1992; Davidson, 1980), a ranking metric is highly relevant to investigate learning issues in a dynamic context.

Entry timing In order to explore further the dynamics of entry, we use a time variable measuring the number of years between firm start-up and entry in the foreign market(s). $40 \%$ of foreign market entries were realized within the first two years of the existence of responding start-ups; 70\% within the 4 first years; and 90\% within the 6 first years. The longest observation was 13 years. As indicated above, entry timing in years is not easy to observe because of time compression. 


\section{Explanatory and Control Variables}

Regulatory environment Following the definition of regulatory environment by North (1990), the first dimension is defined by the legal system implemented in the country, as an historical construct. Because of the key role in business in general and in hi-tech industries in particular, a second dimension is the level of property right protection (Barzel, 1989). Because legal credibility also depends on the capability of legislators to protect long term commitments, a third dimension is the political risk for investors.

Legal systems of countries We employ the classification developed by La Porta et al. (1998 and 1999) that focuses specifically on the legal dimension of countries. La Porta et al. (1999) categorize 212 countries. They determined that 34.4\% of the countries follow English (UK) legal tradition; 43.4\% French legal tradition; 3.3\% Germanic legal tradition; and 2.4\% Scandinavian legal tradition. The remaining thirty-five countries (16.5\%) are represented by various forms of a Socialist legal system (but are absent of the sample because of the IPR variable). As a proxy for the legal system, we select a categorical variable that indicates the legal origin of the foreign country market entered, i.e. French, Scandinavian, English or German, identifies each legal identity.

Political risk There is a long tradition of research demonstrating the influential role of political risk on entry decisions by foreign firms (Shrader et al., 2000; Delios \& Henisz, 2003). The selected “political risk” variable comes from the publication Institutional Investor in 1995. It indicates the extent to which the actions of incumbent governments of the target countries generate uncertainties which may imperil the future value of investments ${ }^{5}$.

\footnotetext{
${ }^{5}$ In order to check the validity of our measure of political risk, we tested alternatively the index suggested by Djankov, LaPorta, Lopez-de-Silanes and Vishny (2000). It is in practice an index of political rights. Higher ratings indicate countries that come closer to the "ideals" defined by the checklist criteria of: (1) free and fair elections; (2) government by freely elected individuals; (3) existence of opposition parties or other competitive political groupings; (4) the opposition has influence and independent authority; and (5) the countries enjoy selfdetermination or an extremely high degree of autonomy. The source is Freedom of the World Data. The
} 
IPR protection Following recent practice (Oxley, 1999; Hagedoorn, Cloodt and van Kranenburg, 2005), we use an intellectual property rights protection index developed by Ginarte and Park (1997). These authors build up a measure on the basis of five categories of patent rights protection: i) the extent of coverage; ii) the participation of a country in international agreements; iii) the provisions for loss of protection; iv) the legal enforcement mechanisms; and v) the duration of protection for a patent. The index is available for 110 countries and we use the values given for the period 1990-1995. The index has a positive value and the greater the value the higher the level of protection of intellectual property rights. (n.b. Unfortunately no data were produced for former Communist countries or Middle East countries. This omission explains the loss of observations in our sample.)

Economic and Business Variables We also introduce complementary variables at country level in order to control for the influence of regulatory factors.

Geographical distance The selection process of the firms could be a function of the geographic proximity of available country markets. In the stage or process models, the typical firm first internationalizes by crossing its borders into neighboring countries. By such means, generating foreign contacts and knowledge are less costly for the new internationalizer given that the "psychic distance" is smaller (Johansson and Vahlne, 1977 and 1990) between contiguous countries. Further, geographical distance is frequently used as a proxy of psychic distance (Benito and Grisprud, 1992; O’Grady and Lane, 1996). In our model, the distance in miles (in natural logarithms) was calculated between London or Berlin, as appropriate, and the capital city of the target market.

Economic size of target countries The annual Gross Domestic Product of each target country is expressed in US \$billions (current prices, IMF figures - World Economic outlook) and calculated logarithmically. Computed as an average on the period 1987-1997, it provides 
a concurrent measure of the economic size and thus the potential commercial attractiveness of the target markets (Delios \& Henisz, 2003).

NTBFs characteristics Start-up preferences in location choices can also depend on their specific features at both transactional and corporate levels. We select separate proxies for these two components.

UK or German Firms Given that we are studying high-tech young firms from two separate nations with different regulatory frameworks, we introduce a proxy indicating the individual nationality of the respondent firms (coded “0” for UK firms and “ 1 ” for German firms).

$\boldsymbol{R} \& \boldsymbol{D}$ intensive firm Because it is generally considered that high technology and $\mathrm{R} \& \mathrm{D}$ efforts are an important driver of internationalization (Henisz, 2000; Shrader, 2001), we introduce a categorical variable describing the degree to which the company is researchoriented. Survey respondents were asked to indicate the 'frequency' of their firm's $R \& D$ activities, i.e. never, occasionally or permanently. We prefer this qualitative variable to an "R\&D expenditure/sales” ratio, as this latter measure is highly volatile and potentially misleading for fast-growth, high-tech companies particularly during the early period after start-up. Generally speaking, the use of accounting and financial data to describe the business models of start-up firms is highly problematic given the early volatility of such measures. Thus, we cannot employ R\&D, marketing or capital investments proxies traditionally used for large and established multinational companies (Delios and Beamish, 1999; Henisz, 2000; Delios and Henisz, 2003).

Previous experience in international business The human capital of founders, particularly their international experience, will influence the choices made by the young firm. Two main streams of experience are defined: i) managers having previously worked abroad (and thus experienced in other regulatory environments) and ii) managers having worked previously in 
a multinational company (and thus experienced in managing in multi-country environments). We thus introduce two dummies.

Firm size We introduce firm size in order to control for differentials in resource endowments between respondents. As we are concerned with the effects of possible constraints of human capital, we measure the number of people working in the company at the time of the survey (i.e. full-time equivalents expressed as a natural logarithm).

Industry We introduce industry dummies to take into account sector influences on entry timing and choice. We classify our sample NTBFs into five generic, hi-tech categories: 'Software’; 'IT and Communications Hardware'; 'Engineering’; 'Life Science and Medical Technology'; and 'Other'.

\section{DATA ANALYSIS AND RESULTS}

The appendix provides descriptive statistics including correlations. As is expected for country features (Busenitz et al., 2000), we note high correlation levels between proxies - the highest being between IPRs and political risk (0.672). One possibility would have been to build up a synthetic index summarizing the regulatory environment. But this would make it impossible to disentangle separate effects between the identified dimensions. Consequently, we systematically checked that our statistical outputs were free of multicolinearity or endogeneity bias by testing that the coefficients remain stable independently of the presence or absence of other country exploratory variables. Considering the match of datasets, we also logically find no correlation between corporate and country variables on the sample of 18,750 observations.

In order to test our hypotheses, we run a series of regression models. For hypotheses 1 to 3 on location choices, we use a binary logistic model on panel data with entries coded “1”, and non-entries coded "0”. This model allows us to identify both country and firm characteristics 
which may increase the propensity to enter foreign markets. The strategic decision to go abroad is in practice indivisible from the first selection of a foreign market. We complement this view using a rank-ordered logistic model with the ranking as the dependent variable. Because we do not have information after the five first entries, we treat the ranking as incomplete. Non-entries are considered as non-ranked alternatives and it is assumed that these markets are less preferred than the ranked alternatives. Thus, our estimations are not compromised by a selection bias resulting from working on realized entries only (Shaver, 1998; Henisz, 2000). Whereas the binary logistic model provides statistically a proportional view of the sample, the ranked-ordered model allows an individual analysis of choices. The corporate characteristics are assumed to remain the same for one NTBF over multiple entries and do not enter in the evaluation of a ranked-ordered model. Accordingly, observations of possible variations between individual preferences are observed by introducing interactions between country and firm features. For clarity, we show in Table 2 only the significant relations of this "exploded logit model”.

In Table 4, we present the outputs for the timing of entry. We use a survival cox regression model in which each entry marks the event data. Non-entries are also taken into account as they are considered as non-realized events. The use of a survival model corrects the bias of truncated time variables. In all the models, we use a robust estimator of variance, which can relax the assumption of the independence of the observations (i.e. independence cannot be assumed for successive market entries made by the same company).

In our three tables, we present regression models with a baseline case (limited to variables on GDP, distance and industry as control variables), plus full models with and without interactions. In order to check the consistency of choices between UK and German firms, we also run a series of regression by nationality of start-ups. The statistical quality of our models shows an improvement in comparison to the reference model. 
The coefficients are generally significant and have the expected sign. The first hypothesis is confirmed. Countries with regulatory environments that protect firms' IPR are noticeably more attractive whatever the country of origin of the start-up. The political risk is also highly significant in the analysis of entry choice or the ranking of entry preferences (Table 1, reg. 1; Table 2, reg.1). In both cases, these two factors influence the growth trajectories of start-ups. German firms appear more sensitive to IPR protection than UK respondents. This country difference is not observed for political risk.

The conclusions are more subtle regarding the impact of the legal framework. At a first glance, the outcomes on the whole sample could suggest that start-ups have a preference for the English system of common law (tables 1 and 2, reg.1, negative coefficients). This is particularly striking in comparison to the French legal system which is also spread worldwide (in contrast to the German or Scandinavian legal systems). But this first impression is contradicted when considering specifically German and English NTBFs. Interactions between the legal system and the nationality of the firms (Tables $1 \& 2$, reg.2) each have a positive coefficient. It shows that German firms are more prone to enter countries with other legal system than the English law system. The analysis of decision making by sub-samples of German and UK start-ups confirms this view. The English NTBFs exhibit a clear preference in favour of countries regulated by common law. Again, despite the fact that countries with French law are numerous, they are noticeably unattractive for English NTBFs. The coefficient is comparable to those for German and Scandinavian countries (albeit there are approximately ten times the numbers of German and Scandinavian law countries). These empirical findings are especially striking for German companies given that the international replication of the German legal system is comparatively rare (only 7 states among 212 countries). The finding that German NTBFs maintain a preference for target countries with strong German regulatory linkages supports the idea that young firms prefer to initiate their internationalization process 
by entry into a market with a very similar regulatory environment. This decision is made by German firms despite the consequent and significant constraints on market choice and sales potential. Comparative analysis of coefficients for regression models on UK and German sub samples show higher values (in absolute terms) for English start-ups. English NTBFs maintain a preference for embedding their international growth within common law countries. German firms do not benefit from equivalent levels of choice and have to expand sooner in other legal systems. This may explain why IPRs protection is more valued by German NTBFs. Note, however, that they exhibit a clear preference for French legal system as a second best choice. In other words, they also prefer to expand abroad in countries regulated under Roman law tradition. These results confirm our second set of hypotheses, H2a and H2b. Managers in NTBFs have a preference for working within a known legal system which is as close as possible to that operating in their home country.

By contrast, managerial experience has a less visible impact on the location decision. It appears that previous experience abroad increases the likelihood of entering foreign markets (albeit at only a 10\% significance threshold, Table 1). No specific effects, however, emerged for the ranked preferences of entries. H3a is not confirmed from that perspective. Results are also influenced by previous experience in a multinational company but only for the German respondents (Table 1, reg. 4). In terms of preferences, experience in a multinational helps managers to better deal with IPR protection (Table 2, reg.2). This is more important for UK NTBFs (Table 2, reg.3). H3b is thus partially confirmed.

The analysis of other variables provides additional insights on entry dynamics (Tables 1 \& 2). First of all, geographical distance significantly influences market location choice. This suggests that the born global phenomenon is still a specific case and that the internationalization process of the "average” NTBF remains subject to spatial and psychic distance factors. The economic and business variables also produce interesting results worthy 
of comment. As expected, the GDP variable is significant and influential across all models. Logically, the economic size of the target country would be expected to remain a critical variable in the ordering of market entry priorities. Fixed costs of market entry can be amortized more effectively in large and important markets. Such markets also frequently represent the best opportunities for advanced market intelligence on both customers and competitors - a potentially critical issue in rapidly changing new technology markets. As regards firm features, firms that permanently engage in $R \& D$ tend to be more international in the UK. This country difference suggests that UK's foreign customers may demand more R\&D intensive goods than domestic customers, an asymmetry not found in Germany. Size at start-up does not appear to influence the foreign entry choice. Note, however, that larger NTBFs seem to be more cautious of political risk. This may be because better endowed NTBFs are more aware of the possible negative consequences of their decisions. By contrast, industry sectors appear to have no effect on location choice.

The analysis of the timing of foreign entries (Table 3) provides complementary lessons to the findings on the internationalization dynamics. Regulatory variables appear much less influential on timing. The country features have generally non-significant coefficients. A noticeable exception is the IPRs variable. Target country markets with low IPR protection are less attractive to internationalizing NTBFs. Note, however, that the dynamics of German firms seem different from their UK competitors. The former are indeed more influenced by the national legal system than the absolute level of IPR protection. In this sense, H5 is partially confirmed but differently for English and German countries. By contrast with the two first sets of regression models, the speed of entry mainly depends on firm-specific rather than country-specific characteristics. This is particularly evident for English NTBFs. In particular, management teams with a professional background in multinationals (more than just experience abroad) have a significant advance in speed. This supports H5 for both UK 
and German firms (Table 3, all reg.). Firm size and (to a lesser degree) permanent R\&D also tends to increase the speed of entry confirming the importance of initial resource endowments. Some industry differences are also visible. In general UK firms appear to be more sensitive than their German peers to variables which influence of speed of internationalization. Given that German firms have the advantage of the largest domestic market in Europe, this may provide some explanation for different behavior in each country.

In summary, our empirical results show that entry locations (Tables 1 \& 2) are substantially influenced by country features. But, the timing of early internationalization appears much more depends on corporate resources, organizational experience and sector effects. These results support the overall thesis of this paper that regulatory environments matter in determining the internationalization dynamics of NTBFs. Within the context of these start-ups, this finding also reinforces the importance of intellectual property rights protection in the internationalization process of new knowledge-based firms.

\section{DISCUSSION}

\section{Overview}

To the best of our knowledge, this study provides the first in depth analysis of the influence of cross country regulatory environments on the internationalization dynamics of NTBFs. It helps contribute to debate within the international business community on two sides: the challenge of traditional patterns of internationalization; and the comparative assessment of regulatory frameworks on international transactions.

First, the classical stage model (Johanson and Vahlne, 1977) dictates that inexperienced firms will prefer to enter first countries that are closer both geographically and culturally to their home market (Davidson, 1980). Recent theoretical contributions have seriously questioned the relevance of this approach for international new ventures (Oviatt and 
McDougall, 1994 and 2005; Zahra, 2005), backed up by initial empirical evidence (Zahra and al., 2000; Shrader and al., 2000). Our findings bring mixed conclusions. Focused on market selection, it appears that the level of IPR protection is a decisive variable in entrepreneurial decision making. Hazards on intellectual capital appropriation or imitation become a first ranked concern and shape the international track of NTBFs. This complements the more traditional and well documented approach of political risk (Delios and Henisz, 2003). But the validity of traditional process theory is also visible in our findings. Psychic distance, measured by geographic distance, is still highly influential and shows that entrepreneurs continue to prefer foreign markets sited close to home. On average, the internationalizing NTBF is no longer a classical SME (Lu and Beamish, 2006) but not yet a "born global" corporation. Following other contributions (Barkema et al., 1996; Zahra et al., 2000; Oviatt and McDougall, 2005; Sapienza et al., 2006), we note, however, that international experience of founding teams is decisive in influencing internationalization patterns, in particular for the issue of speed of entry.

Secondly, our research results support the value of studying the role of regulatory frameworks on the internationalization process. More specifically, we show that the attractiveness of regulatory environments depends not only on protection of IPRs per se (Oxley, 1999; Hagedoorn and al., 2005), but also on the experiential learning acquired by the start-up in its home country. We therefore adopt a cautious and nuanced approach on the role of property rights regime on international business transactions - in particular regarding judgments as to "better” regulatory regimes (La Porta et al., 1998). We seek to demonstrate that it is fruitful in international business studies to disentangle as far as possible complex concepts such as regulatory regimes in order to identify distinct and sometimes contradictory effects on the dynamics of internationalization. 


\section{Limitations and Extensions of the Study}

We first acknowledge that certain information that would have enhanced our analysis is unavailable. We do not possess information on the characteristics/human capital of the exporting entrepreneur(s), especially their nationalities or the countries in which they have previously worked (Andersson, 2000).. We also lack information on any network or social capital activities of the entrepreneurial management teams. Rapidly growing firms are known to be effective users of networks in order to address information and logistical needs (YliRenko et al., 2001; Sapienza et al., 2006). Similarly, the embeddedness of the entrepreneur within key commercial and related social systems can strongly guide the developmental path and subsequent performance of the entrepreneurial young firm (Coviello \& Munro, 1995).

More problematic, we do not know precisely what mode of internationalization channel (e.g. direct exporting or use of an occasional or regular intermediary) is employed on entering a new country market. The importance of mode is certainly true but it is generally appraised once the location choice is made (Teece, 1986). Questions of location and governance can be treated independently of each other as is seen in the research literature. In a recent conceptual paper on the impacts of knowledge transfer capacity on foreign entry modes, Martin and Salomon (2003) explain that "while examining location factors is certainly relevant, particularly in studies with multiple host countries, such country effects do not change our predictions” (p.369). We suggest that this argument may also be inverted, i.e. while examining entry modes is certainly relevant, particularly in studies with multiple entry modes, such governance effects do not change our (location) predictions. In practice, the debate over mode may not be relevant for early stage NTBFs. Our available (but incomplete) information on entries into the respondents' largest foreign markets indicates that the great majority of 
entries are via the capital-extensive entry modes of direct exporting and the use of an agent/distributor ${ }^{6}$.

Finally, while our data are rich in detail, they remain focused exclusively on the actions of NTBFs in two Northern European countries. Our results may not be relevant for young firms outside European new technology environments. It would strengthen the generalizability of our model if corroborating data were available from both high and low-tech firms exporting from other European and non-European home countries.

\section{Conclusion}

We have sought to understand those country factors influencing location choices during the early internationalisation process of a cohort of British and German new technology-based firms. We argue that internationalization research has been strongly conditioned by the predominant examination of large, established and well resourced firms. While this has been challenged in the entrepreneurial field in recent years, it remains the default perspective of many strategy theorists. Large firms, however, have a range of strategic options not available to nascent or young firms. How young firms reacts to opportunities or to environmental and competitive threats will be qualitatively different from the actions of their large firm peers. Issues of transaction costs and intellectual property appropriation threats at the time of new market entry demonstrate a divide between NTBFs and established firms. The latter can absorb considerable unexpected costs resulting from a failed enterprise. For the young and resource-constrained firm, unforeseen costs brought about by unwise or unlucky decisions may well result in its failure. Similarly, an established firm may be able to reduce the threat of intellectual property theft by complex contractual or ownership arrangements with its partners. In the event of such safeguards failing, the firm can resort to litigation. Young firms have rarely the financial resources fully to define contracts nor the management time or

\footnotetext{
${ }^{6}$ Initial findings from a follow-up survey of 1997 respondents in 2003 confirm the continued dominance of capital-extensive modes of internationalization.
} 
discretionary finance to punish predatory actions. Failures are never far from successes for young NTBFs when exposing their core intellectual assets to the complexity of cross country regulations. Accordingly, the initial location decisions of internationalizing, new technology based firms are of major strategic importance. 


\section{References}

Anderson, E. and Coughlan, A. (1987) 'International Market Entry and Expansion via Independent or Integrated Channels of Distribution’, Journal of Marketing, 51: 71-82.

Anderson, E. and Gatignon, H. (1986) 'Modes of foreign market entry: A transaction cost analysis and propositions', Journal of International Business Studies, 17: 1-26.

Andersson, S. (2000) 'The internationalization of the firm from an entrepreneurial perspective’, International Studies of Management and Organisation, 30: 63-92.

Arenius, P. (2005) 'The psychic distance postulate revised: from market selection to speed of market penetration', Journal of International Entrepreneurship, 3, 115-131.

Autio, E. (2005) 'Creative tension: the significance of Ben Oviatt’s and Patricia McDougall’s article 'towards a theory of international new ventures', Journal of International Business Studies, 36: 9-19.

Autio, E., Sapienza, H. and Almeida, J. (2000) 'Effects of age at entry, knowledge intensity, and imitability on international growth’, Academy of Management Journal, 43: 909-924.

Barkema, H. and Vermeulen F. (1997) 'What cultural differences are detrimental for international joint ventures?', Strategic Management Journal, 17: 151-166.

Barkema, H., Bell J. and Pennings J. (1996) 'Foreign entry, cultural barriers, and learning', Journal of International Business Studies, 28: 846-864.

Barzel, Y. (1989) ‘The Economics of Property Rights’, Cambridge University Press.

Benito, G. and Gripsrud G. (1992) 'The expansion of foreign direct investment: discrete rational location choices or a cultural learning process?', Journal of International Business Studies, 23: 461-476.

Birley, S. (1985) 'The role of networks in the entrepreneurial process', Journal of Business Venturing, 1: 107-117.

Buckley, P. (2004) ‘What is International Business?’, Palgrave, Basingstoke, (editor). 
Buckley, P. and Casson, M. (1976) The future of the multinational enterprise, Macmillan: London.

Bürgel, O., Fier, O., Licht, G. and Murray, G. C. (2004) The internationalisation of Young High-Tech Firms; an empirical analysis in Germany and the United Kingdom, ZEW Economic Studies 22. Heidelberg: Physica-Verlag.

Busenitz, L., Gomez, C. and Spencer J. (2000) 'Country institutional profiles: unlocking entrepreneurial phenomena’. Academy of Management Journal, 43: 994-1003.

Butchart, R. (1987) ‘A new UK dDefinition of high-technology industries’, Economic Trends, 400: 82-88.

Dunkelberg, W. C. (1986) 'Entrepreneurship and the initial size of firms', Strategic Management Journal, 7: 53-68.

Cooper, A. C., Gimeno-Gascon, F. J. and Woo, C. Y. (1994) 'Initial human and financial capital as predictors of venture performance’ Journal of Business Venturing, 9: 371-395.

Coviello, N. E. and Munro, H. (1995) 'Growing the entrepreneurial firm: Networking for international market development’, European Journal of Marketing, 29: 49-62.

Cressy, R. (2006) 'Why do most firms die young?’, Small Business Economics, 26:103-116.

Davidson, W. (1980) 'The location of foreign direct investment activity: Country characteristics and experience effects', Journal of International Business Studies, 11: 9-22.

Davis, L. and North, D. (1971) 'Institutional Change and American Economic Growth', Cambridge University Press.

De Clercq, D., Sapienza, H. And Crijns, H. (2005) 'The internationalization of small and medium-sized firms: the role of organizational learning effort and entrepreneurial orientation', Small Business Economics, 24: 409 -419.

Delios, A. and Beamish, P. (1999) 'Ownership strategy of Japanese firms: Transactional, institutional and experience influences’, Strategic Management Journal, 20: 915-933. 
Delios, A. and Henisz, W. (2003) 'Political hazards and the sequence of entry by Japanese firms’, Journal of International Business Studies, 34: 227-241.

Dimitratos, P.and Jones, M. V. (2005) Guest editorial: future directions for international entrepreneurship research’, International Business Review, 14: 119-128.

Djankov, S., La Porta, R. and Lopez-de-Silanes, F. (2002) 'Regulation of entry’, Quarterly Journal of Economics, 117:1-37.

Ginarte, J.C. and Park, W.G. (1997) 'Determinants of patent rights: a cross-national study', Research Policy 26(3): 283-301.

Hagedoorn, J., Cloodt D. and van Kranenburg, H. (2005) 'Intellectual property rights and the governance of international R\&D partnerships', Journal of International Business Studies, 36,: 175-186.

Henisz, W. (2000) 'The Institutional Environment for Multinational Investment', Journal of Law, Economics and Organization, 16: 334-364.

Hennart, J.-F. (1986) 'What is internalization?’ Weltwirtschaftliches Archiv, 122: 791-804.

Johanson, J. and Vahlne, J. (1977) 'The internationalization process of the firm - a model of knowledge development and increasing market commitments', Journal of International Business Studies, 8: 23-32.

Johanson, J. and Vahlne, J. (1990) 'The Mechanism of internationalization', International Marketing Review, 7: 11-24.

Knight, G. and Cavusgil, S. (2004) 'Innovation, organizational capabilities, and the bornglobal firms’, Journal of International Business Studies, 35: 124-141.

La Porta R., Lopez-de-Silanes, F., Schleifer, A. and Vishny, R. (1998) 'Law and finance’, Journal of Political Economy, 106: 1113-1155.

La Porta R., Lopez-de-Silanes, F., Schleifer, A. and Vishny, R. (1999) 'The quality of government', Journal of Law, Economics, and Organization, 15: 222-282. 
Lu, J. and Beamish, P. (2006) 'SME internationalization and performance: growth vs. profitability’, Journal of International Entrepreneurship, 4:27-48.

Madsen, T. and Servais, P. (1997) 'The internationalization of born globals: an evolutionary process?’ International Business Review, 6: 561-583.

Martin, X. And Salomon, R. (2003) 'Knowledge transfer capacity and its implications for the theory of the multinational corporation', Journal of International Business Studies, 34: 356373.

Mascarenhas, B. (1992) 'Order of entry and performance in international markets’, Strategic Management Journal, 13: 499-510.

McDougall, P. and Oviatt, B. (2000) 'International entrepreneurship: the intersection of two research paths', Academy of Management Journal, 43: 902-906.

McDougall, P. P. and Oviatt, B. M. (2000) 'International Entrepreneurship: The Intersection of Two Research Paths’, Academy of Management Journal 43: 902-908.

McDougall, P. P., Shane, S. and Oviatt B. M. (1994) 'Explaining the formation of international new ventures: The limits of theories from international business research', Journal of Business Venturing, 9: 469-488.

McDougall, P. and Oviatt, B. (2005) 'Defining international entrepreneurship and modeling the speed of internationalization', Entrepreneurship Theory \& Practice, September: 537-553. North, D. (1990) Institutions, Institutional Change and Economic Performance, Cambridge University Press: Cambridge.

O’Grady, S. and Lane, H. (1996) 'The psychic distance paradox', Journal of International Business Studies, 27 (2): 309-333.

OECD. (1997) The Oslo Manual - Proposed guidelines for collecting and interpreting technological innovation data, Organization for Economic Cooperation and Development: Paris. 
Ostergard, R. (2000) ‘The measurement of intellectual property rights protection’:, Journal of International Business Studies, 31: 349-360.

Oviatt, B. and McDougall, P. (1994) 'Toward a Theory of International New Ventures', Journal of International Business Studies, 25: 45-64.

Oviatt, B. and McDougall, P. (1995) 'Global start-ups: Entrepreneurs on a worldwide stage', Academy of Management Executive, 9(2): 30-44.

Oxley, J. (1997) ‘Appropriability hazards and governance in strategic alliances: A transaction cost approach’, Journal of Law, Economics and Organization, 13: 387-409.

Oxley, J. (1999) 'Institutional environment and the mechanisms of governance: the impact of intellectual property protection on the structure of inter-firm alliances', Journal of Economic Behavior and Organization, 38: 283-309.

Preece, S., Miles G. and Beats, M. (1998) 'Explaining the international diversity and global intensity of early-stage technology-based firms’ Journal of Business Venturing, 14, 259-281. Reitzig, M. (2004) 'Strategic Management of Intellectual Property’, Sloan Management Review, 45: 35-41.

Rialp, A., Rialp, J. and Knight, G. A. (2005) 'The phenomenon of early internationalizing firms: what do we know after a decade (1993-2003) of scientific enquiry?', International Business Review 14:147-166.

Sapienza, H., Autio, E., George, G. and Zahra S. A. (2006), 'A Capabilities Perspective on the Effects of Early Internationalization on Firm Survival and Growth', Academy of Management Review, 31: 914-933.

Scott, W. (1995) 'Institutions and Organizations’, Thousand Oaks, CA, Sage.

Shrader, R. (2001) 'Collaboration and performance in foreign markets: the case of young high-technology manufacturing firms’, Academy of Management Journal, 44: 45-60. 
Shrader, R., Oviatt B. and McDougall P. (2000) 'How new ventures exploit trade-offs among international risk factors: lessons from the accelerated internationalisation of the $21^{\text {st }}$ century', Academy of Management Journal, 43(6): 1227-1247.

Storey, D. and Tether, B. (1998) 'New technology-based firms in the European Union: an introduction’, Research Policy, 26: 933-946.

Tan, B. and Vertinsky, I. (1996) 'Foreign direct investment by Japanese electronics firms in the United States and Canada: Modelling the timing of entry', Journal of International Business Studies, 27: 655-682.

Teece, D. (1986) 'Transaction cost economics and the multinational enterprise', Journal of Economic Behavior and Organization, 7: 21-45.

Teece, D. (2000) 'Managing Intellectual Capital: Organizational, Strategic, and Policy Dimensions’, Oxford: Oxford University Press.

Thornhill, S. and Amit, R. (2003) 'Learning about failure: Bankruptcy, firm age, and the resource-based view’, Organization Science, 14: 497-509.

Williamson, O. (1991) 'Comparative economic organization: The analysis of discrete structural alternatives’, Administrative Science Quarterly, 36: 269-296.

World Bank (2006) Doing Business in 2006: Creating Jobs. World Bank and International Finance Corporation: Washington DC:

Yli-Renko, H., Autio, E., and Sapienza, H. (2001) 'Social capital, knowledge acquisition, and knowledge exploitation in young technology-based firms’, Strategic Management Journal, 22: 587-613.

Zaheer, S. (1995) 'Overcoming the liability of foreignness', Academy of Management Journal, 38: 341-363.

Zahra, S. (2005) 'A theory of international ventures: a decade of research', Journal of International Business Studies, 36: 20-28. 
Zahra, S. and George, G. (2002) 'Absorptive capacity: a review, reconceptualization, and extension’, Academy of Management Review, 27: 185-203.

Zahra, S., Ireland, R. and Hitt, M. (2000) 'International expansion by new venture firms: international diversity, mode of market entry, technological learning, and performance', Academy of Management Journal, 43: 925-950. 
Table 1

Foreign Entry choices by NTFS (binomial logit model)

\begin{tabular}{|c|c|c|c|c|c|}
\hline Variables & $\begin{array}{l}\text { All cases } \\
\text { (0) }\end{array}$ & All cases (1) & All cases (2) & UK firms & German firms \\
\hline \multirow[t]{2}{*}{ Constant } & $-6.644^{\star \star \star}$ & $-4.724^{\star \star \star}$ & $-3.717^{\star \star \star}$ & 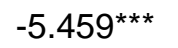 & $-6.420 * \star \star$ \\
\hline & $(0.378)$ & $(0.442)$ & $(0.462)$ & $(0.538)$ & $(0.776)$ \\
\hline \multirow[t]{2}{*}{ French Law } & & $-0.548^{\star \star \star *}$ & 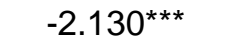 & $-0.943^{\star \star \star}$ & 0.102 \\
\hline & & $(0.108)$ & $(0.273)$ & $(0.139)$ & $(0.140)$ \\
\hline \multirow[t]{2}{*}{ German Law } & & $-0.719 * \star \star$ & $-2.847^{\star \star \star}$ & $-1.172^{\star \star \star}$ & \\
\hline & & $(0.098)$ & $(0.294)$ & (0.119) & \\
\hline \multirow[t]{2}{*}{ Scandinavian Law } & & $-0.766^{\star \star \star}$ & $-1.983^{\star \star \star}$ & $-0.918^{\star \star \star}$ & $-0.403^{*}$ \\
\hline & & $(0.124)$ & $(0.339)$ & $(0.147)$ & $(0.198)$ \\
\hline \multirow[t]{2}{*}{ English Law } & & & & & $-0.456^{\star \star}$ \\
\hline & & & & & $(0.194)$ \\
\hline \multirow[t]{2}{*}{ IPRs } & & $0.576^{\star \star \star}$ & $0.603^{\star \star *}$ & $0.318^{\star \star \star}$ & $1.125^{\star \star \star}$ \\
\hline & & $(0.068)$ & $(0.070)$ & $(0.082)$ & $(0.151)$ \\
\hline \multirow{2}{*}{ Political Risk } & & $-0.029 * \star \star$ & $-0.031 * * *$ & $-0.026^{\star \star \star}$ & $-0.032^{* * *}$ \\
\hline & & $(0.004)$ & $(0.004)$ & (0.005) & $(0.008)$ \\
\hline \multirow[t]{2}{*}{ Geographic distance (In) } & $-0.468^{\star \star \star}$ & $-0.315^{\star \star \star}$ & 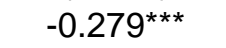 & $-0.387^{\star \star \star}$ & $-0.182^{\star * *}$ \\
\hline & $(0.023)$ & $(0.033)$ & $(0.035)$ & $(0.049)$ & $(0.047)$ \\
\hline \multirow{2}{*}{ Gdp (In) } & $0.588^{\star * \star}$ & $0.293^{\star \star \star}$ & $0.291^{\star * \star}$ & $0.450 * \star \star *$ & $0.118^{\star \star \star}$ \\
\hline & $(0.022)$ & $(0.021)$ & $(0.022)$ & $(0.032)$ & $(0.023)$ \\
\hline \multirow[t]{2}{*}{ German Firm } & & $-0.316^{\star \star \star}$ & $-1.397^{* \star *}$ & & \\
\hline & & $(0.072)$ & $(0.168)$ & & \\
\hline \multirow{2}{*}{ Size at start-up (In) } & -0.001 & 0.034 & 0.034 & 0.027 & 0.058 \\
\hline & $(0.130)$ & $(0.036)$ & $(0.036)$ & $(0.049)$ & $(0.054)$ \\
\hline \multirow[t]{2}{*}{ Occasional R\&D } & 0.001 & 0.026 & 0.027 & 0.067 & -0.067 \\
\hline & $(0.130)$ & (0.132) & (0.133) & $(0.171)$ & $(0.212)$ \\
\hline \multirow[t]{2}{*}{ Permanent R\&D } & $0.265^{\star}$ & $0.286^{\star \star}$ & $0.289 * \star$ & $0.382^{* *}$ & 0.109 \\
\hline & $(0.116)$ & (0.118) & $(0.119)$ & $(0.154)$ & (0.192) \\
\hline \multirow[t]{2}{*}{ Experience abroad } & & $0.104^{\circ}$ & $0.105)^{\circ}$ & 0.109 & 0.090 \\
\hline & & $(0.066)$ & $(0.066)$ & $(0.081)$ & (0.118) \\
\hline \multirow[t]{2}{*}{ Experience in a multinational } & & 0.079 & 0.080 & -0.010 & $0.271^{\star \star}$ \\
\hline & & $(0.065)$ & $(0.065)$ & $(0.079)$ & $(0.115)$ \\
\hline \multirow[t]{2}{*}{ Engineering } & -0.033 & -0.043 & -0.044 & -0.002 & -0.151 \\
\hline & $(0.114)$ & $(0.116)$ & $(0.117)$ & (0.139) & $(0.218)$ \\
\hline \multirow[t]{2}{*}{ IT and comm. hardware } & -0.069 & -0.078 & -0.079 & -0.084 & -0.152 \\
\hline & $(0.112)$ & $(0.114)$ & $(0.114)$ & $(0.136)$ & $(0.217)$ \\
\hline \multirow[t]{2}{*}{ Other ind. } & -0.170 & -0.138 & -0.140 & -0.170 & -0.058 \\
\hline & (0.113) & $(0.115)$ & (0.115) & $(0.143)$ & $(0.200)$ \\
\hline \multirow[t]{2}{*}{ Software and ITservices } & -0.165 & -0.169 & -0.171 & -0.187 & -0.130 \\
\hline & $(0.115)$ & (0.115) & $(0.116)$ & $(0.136)$ & $(0.223)$ \\
\hline \multirow[t]{2}{*}{ French Law x German Firm } & & & $1.319 * \star *$ & & \\
\hline & & & (0.198) & & \\
\hline \multirow[t]{2}{*}{ German Law x German Firm } & & & $1.668^{\star \star *}$ & & \\
\hline & & & $(0.218)$ & & \\
\hline \multirow[t]{2}{*}{ Scandinavian Law x German Firm } & & & $1.029 * \star \star$ & & \\
\hline & & & $(0.254)$ & & \\
\hline Log likelihood & -3812.884 & -3635.649 & -3599.223 & -2458.66 & -1108.804 \\
\hline Wald Chi2 & $1228.75^{\star \star \star}$ & $1353.94^{\star \star \star}$ & $1323.97^{\star \star *}$ & $929.96 * \star \star$ & $317.7^{\star \star \star}$ \\
\hline Number of cases & 18750 & 18750 & 18750 & 12000 & 6750 \\
\hline
\end{tabular}

Coefficients significant at 1\%o (***); 1\% (**); 5\% (*); $10 \%\left(^{\circ}\right)$.

Reference industry: Life Sc. and Med. Tech.; Robust standard errors in brackets. 
Table 2

Preferences of Foreign Entries by NTFS (rank-ordered logistic regression model)

\begin{tabular}{|c|c|c|c|c|c|c|c|}
\hline Variables & All cases & All cases (1) & All cases (2) & UK firms & & German firms & \\
\hline French Law & & $\begin{array}{r}-0.466^{\star \star \star} \\
(0.108)\end{array}$ & $\begin{array}{r}-1.882^{\star \star \star} \\
(0.271)\end{array}$ & $\begin{array}{r}-0.848^{\star \star \star} \\
(0.137)\end{array}$ & $\begin{array}{r}-0.849 * * * \\
(0.137)\end{array}$ & $\begin{array}{r}0.104 \\
(0.127)\end{array}$ & $\begin{array}{r}0.105 \\
(0.127)\end{array}$ \\
\hline German Law & & $\begin{array}{r}-0.624^{* \star *} \\
(0.091)\end{array}$ & $\begin{array}{r}-2.398^{\star \star *} \\
(0.277)\end{array}$ & $\begin{array}{r}-0.978^{* \star *} \\
(0.106)\end{array}$ & $\begin{array}{r}-0.983^{* \star *} \\
(0.107)\end{array}$ & $\begin{array}{l}-0.368^{\star} \\
(0.205)\end{array}$ & \\
\hline Scandinavian Law & & $\begin{array}{r}-0.666^{\star \star \star} \\
(0.129)\end{array}$ & $\begin{array}{r}-1.730 * \star \star \\
(0.361)\end{array}$ & $\begin{array}{r}-0.802^{\star \star \star} \\
(0.154)\end{array}$ & $\begin{array}{r}-0.799 * * * \\
(0.154)\end{array}$ & $\begin{array}{r}-0.461^{\star *} \\
(0.150)\end{array}$ & $\begin{array}{l}-0.366^{\star} \\
(0.205)\end{array}$ \\
\hline English Law & & & & & & $\begin{array}{r}-0.461^{\star *} \\
(0.150)\end{array}$ & $\begin{array}{r}-0.462^{\star *} \\
(0.149)\end{array}$ \\
\hline IPRs & & $\begin{array}{r}0.522^{\star * *} \\
(0.062)\end{array}$ & $\begin{array}{r}0.420 * * * \\
(0.087)\end{array}$ & $\begin{array}{l}0.233^{\star *} \\
(0.073)\end{array}$ & $\begin{array}{r}0.065 \\
(0.097)\end{array}$ & $\begin{array}{r}1.113^{* * *} \\
(0.140)\end{array}$ & $\begin{array}{r}1.171^{\star \star *} \\
(0.177)\end{array}$ \\
\hline Political Risk & & $\begin{array}{r}-0.030 * \star * \\
(0.003)\end{array}$ & $\begin{array}{r}-0.023^{\star * *} \\
(0.005)\end{array}$ & $\begin{array}{r}-0.025^{\star \star \star} \\
(0.004)\end{array}$ & $\begin{array}{r}-0.017^{\star *} \\
(0.006)\end{array}$ & $\begin{array}{r}-0.031^{\star \star *} \\
(0.006)\end{array}$ & $\begin{array}{r}-0.027^{\star *} \\
(0.011)\end{array}$ \\
\hline Geographic distance (In) & $\begin{array}{r}-0.422^{\star \star \star} \\
(0.022)\end{array}$ & $\begin{array}{r}-0.293^{\star \star *} \\
(0.029)\end{array}$ & $\begin{array}{r}-0.260 * \star \star \\
(0.030)\end{array}$ & $\begin{array}{r}-0.389 * * * \\
(0.048)\end{array}$ & $\begin{array}{r}-0.390 * * * \\
(0.048)\end{array}$ & $\begin{array}{r}-0.165^{\star \star \star} \\
(0.034)\end{array}$ & $\begin{array}{r}-0.165^{\star \star *} \\
(0.035)\end{array}$ \\
\hline Gdp (In) & $\begin{array}{r}0.563^{* * *} \\
(0.026)\end{array}$ & $\begin{array}{r}0.269 * * \star \\
(0.022)\end{array}$ & $\begin{array}{r}0.259 * \star * \\
(0.023)\end{array}$ & $\begin{array}{r}0.423^{\star * *} \\
(0.033)\end{array}$ & $\begin{array}{r}0.421^{\star \star \star} \\
(0.033)\end{array}$ & $\begin{array}{r}0.104^{* * *} \\
(0.019)\end{array}$ & $\begin{array}{r}0.104^{\star * *} \\
(0.019)\end{array}$ \\
\hline French Law x German Firm & & & $\begin{array}{c}1.198 * \star \star \\
(0.194)\end{array}$ & & & & \\
\hline German Law x German Firm & & & $\begin{array}{r}1.407^{\star \star \star} \\
(0.201)\end{array}$ & & & & \\
\hline Scandinavian Law x German Firm & & & $\begin{array}{r}0.912^{\star \star \star} \\
(0.268)\end{array}$ & & & & \\
\hline Political Risk x Size at start_up (In) & & & $\begin{array}{l}-0.007^{*} \\
(0.003)\end{array}$ & & $\begin{array}{l}-0.008^{\star} \\
(0.004)\end{array}$ & & $\begin{array}{r}-0.003 \\
(0.006)\end{array}$ \\
\hline IPRs $x$ Experience in a multinational & & & $\begin{array}{c}0.237^{*} \\
(0.107)\end{array}$ & & $\begin{array}{l}0.310^{\star *} \\
(0.110)\end{array}$ & & $\begin{array}{r}-0.105 \\
(0.277)\end{array}$ \\
\hline Log likelihood & -4061.5 & -3895.252 & -3856.109 & -2718.581 & -2711.169 & -1110.056 & -1109.72 \\
\hline Wald Chi2 & $937.30^{\star \star \star}$ & $1142.34^{\star \star \star}$ & $1142.34^{\star \star \star}$ & $691.12^{\star \star \star}$ & $789.57^{\star \star \star}$ & $237.78^{\star \star \star}$ & $247.10^{\star \star \star}$ \\
\hline Number of cases & 18750 & 18750 & 18750 & 12000 & 12000 & 6750 & 6750 \\
\hline
\end{tabular}

Coefficients significant at 1\%o (***); $1 \%\left({ }^{* *}\right) ; 5 \%(*) ; 10 \%\left(^{\circ}\right)$.

Reference industry: Life Sc. and Med. Tech.; Robust standard errors in brackets. 
Table 3 Foreign Entry timing by NTBFs (cox regression)

\begin{tabular}{|c|c|c|c|c|c|}
\hline Variables & $\begin{array}{l}\text { All } \\
\text { cases } \\
(0)\end{array}$ & All cases (1) & All cases $(2)$ & UK firms & German firms \\
\hline \multirow[t]{2}{*}{ French Law } & & 0.957 & 0.999 & 1.007 & $0.773^{\star \star}$ \\
\hline & & $(0.077)$ & $(0.207)$ & $(0.096)$ & $(0.089)$ \\
\hline \multirow[t]{2}{*}{ German Law } & & 1.088 & 0.837 & 1.017 & \\
\hline & & $(0.083)$ & $(0.197)$ & $(0.093)$ & \\
\hline \multirow[t]{2}{*}{ Scandinavian Law } & & 0.988 & 1.524 & 1.166 & $0.676^{*}$ \\
\hline & & $(0.096)$ & $(0.429)$ & $(0.138)$ & $(0.103)$ \\
\hline \multirow[t]{2}{*}{ English Law } & & & & & 1.080 \\
\hline & & & & & $(0.234)$ \\
\hline \multirow[t]{2}{*}{ IPRs } & & $1.152^{\star \star}$ & $1.117^{\star}$ & $1.126 *$ & 0.958 \\
\hline & & $(0.060)$ & $(0.060)$ & $(0.074)$ & $(0.106)$ \\
\hline \multirow[t]{2}{*}{ Political Risk } & & 1.000 & 1.000 & 1.000 & 1.002 \\
\hline & & $(0.003)$ & $(0.003)$ & $(0.004)$ & $(0.006)$ \\
\hline \multirow[t]{2}{*}{ Geographic distance (In) } & $0.964^{*}$ & 0.984 & 0.977 & 1.001 & $0.818^{*}$ \\
\hline & $(0.018)$ & $(0.031)$ & $(0.032)$ & $(0.037)$ & $(0.075)$ \\
\hline \multirow[t]{2}{*}{ Gdp (In) } & 0.995 & $0.953^{\star}$ & 0.971 & 0.971 & 1.006 \\
\hline & $(0.016)$ & $(0.023)$ & $(0.025)$ & $(0.033)$ & $(0.046)$ \\
\hline \multirow[t]{2}{*}{ German Firm } & & 0.960 & 0.973 & & \\
\hline & & $(0.058)$ & $(0.136)$ & & \\
\hline \multirow[t]{2}{*}{ Size at start-up (In) } & $1.079 \star \star$ & $1.086^{\star \star}$ & $1.087^{\star \star}$ & $1.177^{\star \star \star}$ & 0.996 \\
\hline & $(0.030)$ & $(0.031)$ & $(0.031)$ & $(0.043)$ & $(0.046)$ \\
\hline \multirow[t]{2}{*}{ Occasional R\&D } & 0.982 & 1.064 & 1.072 & 1.127 & 0.949 \\
\hline & $(0.108)$ & $(0.121)$ & $(0.124)$ & $(0.173)$ & $(0.163)$ \\
\hline \multirow[t]{2}{*}{ Permanent R\&D } & $0.783^{\star}$ & $0.845^{\circ}$ & $0.845^{\circ}$ & 0.816 & 0.890 \\
\hline & $(0.076)$ & $(0.087)$ & $(0.089)$ & $(0.114)$ & $(0.137)$ \\
\hline \multirow[t]{2}{*}{ Experience abroad } & & 1.017 & 1.014 & 1.060 & 1.000 \\
\hline & & $(0.053)$ & $(0.053)$ & $(0.068)$ & $(0.102)$ \\
\hline \multirow[t]{2}{*}{ Experience in a multinational } & & $1.208^{\star * \star}$ & $1.208^{\star \star *}$ & $1.232^{\star \star \star}$ & $1.290^{\star *}$ \\
\hline & & $(0.060)$ & $(0.061)$ & $(0.073)$ & $(0.121)$ \\
\hline \multirow[t]{2}{*}{ Engineering } & $0.731^{\star \star \star}$ & $0.709 * \star \star$ & $0.700 * \star \star$ & $0.633^{\star \star *}$ & 1.034 \\
\hline & $(0.062)$ & $(0.059)$ & $(0.059)$ & $(0.060)$ & $(0.179)$ \\
\hline \multirow[t]{2}{*}{ IT and comm. hardware } & $0.796 * \star$ & $0.795^{\star \star}$ & $0.787^{\star \star}$ & $0.786^{* *}$ & 0.872 \\
\hline & $(0.062)$ & $(0.061)$ & $(0.060)$ & $(0.076)$ & $(0.123)$ \\
\hline \multirow[t]{2}{*}{ Other ind. } & $0.720^{\star \star *}$ & $0.722^{\star \star \star}$ & $0.717^{* \star \star}$ & $0.668^{\star \star \star}$ & 0.840 \\
\hline & $(0.055)$ & $(0.054)$ & $(0.053)$ & $(0.063)$ & $(0.107)$ \\
\hline \multirow[t]{2}{*}{ Software and ITservices } & $0.660^{\star \star \star}$ & $0.660 * \star \star$ & $0.655^{\star \star \star}$ & $0.555^{\star \star \star}$ & 1.094 \\
\hline & $(0.052)$ & $(0.052)$ & $(0.052)$ & $(0.055)$ & $(0.153)$ \\
\hline \multirow[t]{2}{*}{ French Law x German Firm } & & & 0.964 & & \\
\hline & & & $(0.156)$ & & \\
\hline \multirow[t]{2}{*}{ German Law x German Firm } & & & 1.202 & & \\
\hline & & & $(0.219)$ & & \\
\hline \multirow[t]{2}{*}{ Scandinavian Law x German Firm } & & & 0.729 & & \\
\hline & & & $(0.155)$ & & \\
\hline \multirow[t]{2}{*}{ Log likelihood } & - & -7748.963 & -7746.435 & -5142.058 & -1847.919 \\
\hline & 7757.973 & & & & \\
\hline Wald Chi2 & $64.01^{* * *}$ & $96.73^{\star \star \star}$ & $100.45^{\star \star \star}$ & $105.97^{\star \star \star *}$ & $26.99 * *$ \\
\hline Number of cases & 1235 & 1235 & 1235 & 870 & 365 \\
\hline
\end{tabular}

Hazard ratios significant at 1\%o (***); 1\% (**); 5\% (*); 10\% ( $\left.{ }^{\circ}\right)$.

Reference industry: Life Sc. and Med. Tech.; Robust standard errors in brackets. 
Appendix: Descriptive statistics and Pearson correlations among variables

\begin{tabular}{|c|c|c|c|c|c|c|c|c|c|c|c|c|c|c|}
\hline VariableS & Mean & Std. Dev. & (1) & (2) & (3) & (4) & (5) & (6) & (7) & (8) & (9) & (10) & (11) & (13) \\
\hline 1. French Law & 0.44 & 0.50 & 1.00 & & & & & & & & & & & \\
\hline 2. German Law & 0.12 & 0.32 & $-0.328 *$ & 1.00 & & & & & & & & & & \\
\hline 3. Scandinavian Law & 0.10 & 0.30 & $-0.295^{*}$ & $-0.123^{*}$ & 1.00 & & & & & & & & & \\
\hline 4. Political Risk & 31.28 & 21.00 & $0.293^{*}$ & $-0.398 *$ & $-0.245 *$ & 1.00 & & & & & & & & \\
\hline 5. IPRs & 2.94 & 0.89 & $-0.330 *$ & $0.431^{*}$ & $0.243^{*}$ & $-0.672 *$ & 1.00 & & & & & & & \\
\hline 6. Gdp (ln) & 11.62 & 1.83 & $-0.027^{*}$ & $0.140^{*}$ & $0.100 *$ & $-0.437 *$ & $0.354 *$ & 1.00 & & & & & & \\
\hline 7. Geographic distance (ln) & 7.60 & 1.18 & $-0.101^{*}$ & $-0.191 *$ & $-0.311^{*}$ & $0.551^{*}$ & $-0.514^{*}$ & $-0.125^{*}$ & 1.00 & & & & & \\
\hline 8. German Firm & 1.36 & 0.48 & 0.00 & 0.00 & 0.00 & 0.00 & 0.00 & 0.00 & -0.02 & * 1.0000 & & & & \\
\hline 9. Occasional R\&D & 0.23 & 0.42 & 0.00 & 0.00 & 0.00 & 0.00 & 0.00 & 0.00 & 0.00 & $0.032 *$ & 1.00 & & & \\
\hline 10. Permanent R\&D & 0.67 & 0.47 & 0.00 & 0.00 & 0.00 & 0.00 & 0.00 & 0.00 & 0.00 & $-0.048 *$ & $-0.780 *$ & 1.00 & & \\
\hline 11. Experience abroad & 0.52 & 0.50 & 0.00 & 0.00 & 0.00 & 0.00 & 0.00 & 0.00 & 0.00 & $-0.202 *$ & $-0.028 *$ & -0.01 & 1.00 & \\
\hline 12. Experience in a multinational & 0.54 & 0.50 & 0.00 & 0.00 & 0.00 & 0.00 & 0.00 & 0.00 & 0.00 & $-0.086 *$ & $0.015^{*}$ & $-0.049 *$ & $0.149 *$ & 1.00 \\
\hline 13. Size at start-up (ln) & 1.25 & 0.91 & 0.00 & 0.00 & 0.00 & 0.00 & 0.00 & 0.00 & 0.00 & $0.191 *$ & $-0.046^{*}$ & $-0.034 *$ & $-0.058 *$ & $-0.031 *$ \\
\hline 14. Engineering & 0.19 & 0.39 & 0.00 & 0.00 & 0.00 & 0.00 & 0.00 & 0.00 & 0.00 & -0.01 & 0.01 & 0.01 & $0.062 *$ & $0.098 *$ \\
\hline 15. IT and comm. hardware & 0.22 & 0.42 & 0.00 & 0.00 & 0.00 & 0.00 & 0.00 & 0.00 & 0.00 & $-0.025 *$ & $-0.074 *$ & $0.123 *$ & $0.088^{*}$ & -0.01 \\
\hline 16. Other ind. & 0.25 & 0.43 & 0.00 & 0.00 & 0.00 & 0.00 & 0.00 & 0.00 & 0.00 & $0.092 *$ & $0.069 *$ & $-0.124 *$ & $-0.085^{*}$ & $-0.032 *$ \\
\hline 17. Software and ITservices & 0.23 & 0.42 & 0.00 & 0.00 & 0.00 & 0.00 & 0.00 & 0.00 & 0.00 & $-0.048^{*}$ & 0.00 & $-0.059 *$ & $-0.053^{*}$ & $-0.048^{*}$ \\
\hline
\end{tabular}

$\mathrm{N}=18750 ; *=$ significant at $5 \%$ threshold

\begin{tabular}{lrrrr}
\hline VariableS & $(14)$ & $(15)$ & $(16)$ & $(17)$ \\
13. Size at start-up (ln) & 1.00 & & & \\
14. Engineering & $-0.091^{*}$ & 1.00 & & \\
15. IT and comm. Hardware & $-0.032^{*}$ & $-0.26^{*}$ & 1.00 & \\
16. Other ind. & $0.126^{*}$ & $-0.28^{*}$ & $-0.308^{*}$ & 1.00 \\
17. Software and ITservices & $-0.015^{*}$ & $-0.26^{*}$ & $-0.289^{*}$ & $-0.313^{*}$ \\
\hline
\end{tabular}

$\mathrm{N}=18750 ; *=$ significant at $5 \%$ threshold 